\title{
大腿四頭筋セッティングの肢位の違いが 筋活動に及ぼす影響
}

\author{
Effect of Quadriceps Setting in Different Positions on Muscle Activity
}

稲田 竜太 ${ }^{1,2)}$ 三谷 保弘 ${ }^{2,3)}$ 植田 篤史 ${ }^{2,4)}$

RYUTA INADA, RPT ${ }^{1,2)}$, YASUHIRo MITANI, RPT, PhD ${ }^{2,3)}$, ATSUSHI UEDA, RPT ${ }^{2,4)}$

${ }^{1)}$ Department of Rehabilitation, Shimada Hospital: 100-1 Kashiyama, Habikino-shi, Osaka 583-0875, Japan TEL+81 72-953-1001 E-mail: inachan1_8@yahoo.co.jp

2) Department of Sports Physical Therapy, Therapeutic Exercise Research Laboratory, Kansai University of Welfare Sciences

${ }^{3)}$ Department of Rehabilitation Sciences, Faculty of Allied Health Sciences, Kansai University of Welfare Sciences

4) Department of Rehabilitation, Hankai Hospital

Rigakuryoho Kagaku 33(2): 209-213, 2018. Submitted Aug. 24, 2017. Accepted Oct. 13, 2017.

ABSTRACT: [Purpose] To investigate the effects of quadriceps setting in different positions on quadriceps femoris muscle activity. [Subjects and Methods] Ten healthy males performed single-leg quadriceps setting in the supine and prone positions. Single-leg quadriceps setting in the prone position was performed with the hip on the non-supported side either extended at $0^{\circ}$ or maximally extended. Surface electromyography was used to measure the muscle activities of the rectus femoris, vastus medialis, and vastus lateralis on the supported side during single-leg quadriceps setting. [Results] The activity of the rectus femoris muscle was significantly increased by single-leg quadriceps setting in the prone position with the hip maximally extended on the non-supported side. [Conclusion] The results suggest that performing single-leg quadriceps setting in the prone position with the hip maximally extended on the nonsupported side increases the activity of the rectus femoris muscle on the supported side.

Key words: rectus femoris muscle, electromyogram, muscle activity

要旨：〔目的〕大腿四頭筋セッティングの肢位の違いが, 大腿四頭筋の筋活動に及ぼす影響について検討した。〔対象 と方法了健常男性 10 名を対象とし, 背臥位ならびに腹臥位でのセッティングを実施した。腹臥位でのセッティング は片脚で行い, 非支持側の股関節を伸展 $0^{\circ}$ と最大伸展位の 2 つに設定した。このときの支持側の大腿直筋，内側広筋， 外側広筋の筋活動を表面筋電計にて計測した。〔結果〕非支持側の股関節を最大伸展位にした腹臥位でのセッティン グは, 他の肢位に比べて支持側の大腿直筋の筋活動が有意に増大した。〔結語〕大腿四頭筋セッティングは, 腹臥位 にて非支持側の股関節を最大伸展位にすることで支持側の大腿直筋の筋活動が増大することが示唆された. キーワード : 大腿直筋, 筋電図, 筋活動

\footnotetext{
1) 運動器ケア しまだ病院 リハビリテーション課：大阪府羽曳野市樫山 100-1（テ 583-0875) TEL 072-953-1001

2) 関西福祉科学大学 リハビリテーション科学研究室 スポーツ理学療法部門

3) 関西福祉科学大学 保健医療学部 リハビリテーション学科

4) 阪堺病院リハビリテーション部

受付日 2017 年 8 月 24 日 受理日 2017 年 10 月 13 日
} 


\section{I. はじめに}

大腿四頭筋は，膝関節の安定性や衝撃吸収，姿勢保持 などに影響を及ぼし，日常生活やスポーツなどあらゆる 動作の遂行に重要な役割を担う 1-3). 大腿四頭筋は抗重 力筋であることから ${ }^{4)}$, 長期臥床や非荷重などにより筋 萎縮や筋力低下が生じやすい 5). 大腿四頭筋の筋力低下 は安定した動作の遂行を阻害し，高齢者では転倒の要因 にもなるため 6-8)，積極的な筋力強化が行われる。しか し, 下肢の整形外科的疾患の受傷後あるいは術後では, 大腿四頭筋の筋力強化における患部周辺への物理的ス卜 レスの影響を考慮しなければならず，外力による抵抗負 荷の伴わない大腿四頭筋セッティング（以下，セッティ ング）が行われることが多い

セッティングは等尺性収縮を利用した筋力増強運動の ことであり 9)，外力による抵抗負荷を与えないことから ギプス固定中や疼痛などにより関節運動が行えない場合 においても実施することができる。セッティングは変形 性膝関節症に対する運動療法としても推奨されてお り 10)，関節に対する物理的ストレスを抑制し安全に実 施することができる。しかし，抵抗負荷を与えないこと から十分な筋活動が得られるとは限らず，より効果的な セッティングの方法について検討する必要がある。セッ ティングは腹臥位にて行われることも多く，臨床的にも 有用性が高いことが報告されている。羽崎らは，つま先 を床面に接地した腹臥位でのセッティングは背臥位や長 座位，立位でのセッティングと比較して大腿直筋の筋活 動が増大し，臥床時期の筋力強化の方法として考慮す心゙ きと報告している11).

また，腹臥位での片脚セッティングは背臥位でのセッ ティングに比べて姿勢が不安定になりやすく，姿勢制御 に関連する大腿四頭筋の筋活動が誘発されやすいと考え られる，井原らは足趾の機能向上により筋反応やバラン ス能力が改善したと報告しており，これは足底のメカノ レセプターが賦活されたことが要因であると考察してい る 12)。つま先を床面に接地して行う片脚セッティング においても足底のメカノレセプターが賦活され，大腿四 頭筋などの筋反応が生じやすいと推察される。

一側下肢の筋活動は，対側下肢の肢位や運動により変 化することが知られている。河村らは，一側下肢の脚伸 展運動（レッグプレス）を対側股関節の屈曲運動と同時 に行うことで，単独で行うよりもレッグプレス側の大殿 筋とハムストリングスの筋活動が有意に増大し, 大腿直 筋の筋活動が有意に減少したと報告している ${ }^{13)}$ 。また, Nakajima らは背臥位でのセッティングにおいて対側の 下肢を挙上させることで，七ッティング側のハムストリ ングスの筋活動が有意に増大したと報告している ${ }^{14)}$. つまり，一側下肢の一方向の運動は対側下肢の反対方向 の運動とそれに関連する筋活動を引き起こすと考えられ
る.このことから, 腹臥位で行う片脚セッティングにお いても，空間に保持した非支持側の股関節を伸展位に保 持することで支持側の股関節屈曲運動が誘発され，大腿 直筋をはじめとする大腿四頭筋の筋活動が増大すると考 えられる。このことが明らかとなれば，外力による抵抗 負荷を与えなくとも大腿四頭筋の大きな筋活動が得られ， 安全かつ効果的な筋力強化の方法として応用可能である と考えられる。しかし，腹臥位でのセッティングにおけ る非支持側の股関節伸展が支持側の大腿四頭筋の筋活動 に及ぼす影響については十分に検討されていない.

本研究では, 腹臥位での片脚セッティングにおける非 支持側の股関節伸展が大腿四頭筋の筋活動に及ぼす影響 について検討することを目的とした，また，腹臥位での 片脚セッティングと従来から行われている背臥位での セッティングの大腿四頭筋の筋活動を比較し, 効果的な セッティングの方法について検討することを目的とした．

\section{II. 対象と方法}

\section{1. 対象}

対象は，下肢および体幹に整形外科的疾患の既往を有 さない健常男性 10 名（年齢 $21.5 \pm 2.1$ 歳, 身長 $172.2 \pm$ $6.0 \mathrm{~cm}$, 体重 $64.9 \pm 7.0 \mathrm{~kg}$; 平均 \pm 標準偏差）とした。 全ての対象者に研究目的と内容の説明を十分に行い, 研 究参加の同意を得た。 なお, 本研究は関西福祉科学大学 研究倫理委員会の承認を得て実施した（承認番号 17-22）.

\section{2. 方法}

セッティングは，肢位(1)：背臥位でのセッティング, 肢位(2)：腹臥位にて非支持側股関節を伸展 $0^{\circ}$ に保持し た片脚セッティング，肢位(3)：腹臥位にて非支持側股関 節を最大伸展位に保持した片脚セッティングの 3 つの肢 位（図 1）で行い，いずれもセッティング対象側である 利き足（全例右）の膝関節を完全伸展し大腿四頭筋を最 大限に収縮するように指示した。なお，肢位(1)では足関 節は背屈位, 股関節内外転・内外旋は中間位とした，肢 位(2)と (3)では支持側の足関節は底背屈 $0^{\circ}$, 股関節内外 転・内外旋は中間位，非支持側下肢の膝関節は完全伸展 位とし，骨盤の回旋や後退が生じないように体幹前面を 床面に接地した。

計測にはアンプ内蔵型表面筋電計（SX230FW， Biometrics 社製）を使用した。サンプリング周波数は $1000 \mathrm{~Hz}$ とした。被験筋は利き足の大腿直筋（rectus femoris : RF), 内側広筋 (vastus medialis：以下, VM), 外側広筋（vastus latelalis：以下, VL）とし, 十分な皮 膚処理を行った後に筋電図電極（Blue Sensor P-00-S, $\mathrm{Ambu}$ 社製）を貼付した。アース電極は右の手関節前面 に貼付した。計測に先がけて，徒手筋力検査法 15)に準 じて各被験筋の最大筋力発揮時の筋活動を 3 秒間計測 


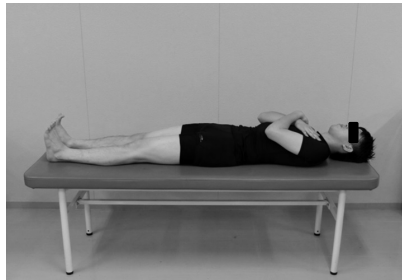

肢位(1)

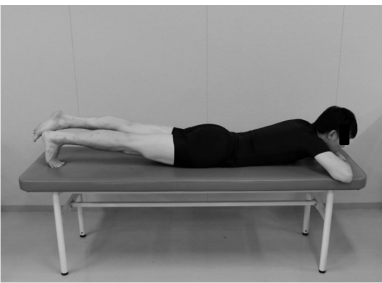

肢位(2)

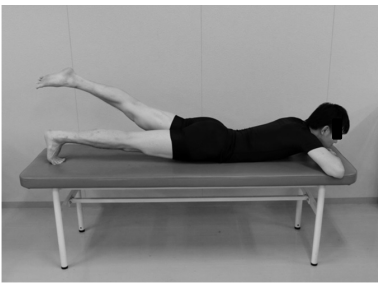

肢位(3)

図 1 大腿四頭筋セッティングの肢位

大腿四頭筋セッティングは, 肢位(1)：背臥位でのセッティング, 肢位(2)：腹臥位にて非 支持側股関節を伸展 0 にに保持した片脚セッティング, 肢位(3)：腹臥位にて非支持側股 関節を最大伸展位に保持した片脚セッティングの3つの肢位で行った.

し, 間 2 秒間の積分值 (integrated electromyogram :

IEMG）を求めた。各運動課題の順番は無作為とし, 計 測回数はそれぞれ 1 回とした。なお，筋疲労の影響を考 慮し各運動課題の間には十分な休息を設けた。

表面筋電計のデー夕処理には解析ソフトウエア (TRIAS，ディケイエイチ社製）を用い，筋電図の原波 形をバンドパスフィルタ $(10-450 \mathrm{~Hz})$ にて処理後, 全 波整流し, ローパスフィルタ $(20 \mathrm{~Hz})$ にて平滑化した. 計測は 3 秒間とし間 2 秒間の IEMG を求め, 最大筋力 発揮時の IEMG に対する割合（\% IEMG）を算出した。

統計解析は, 肢位の違いによる各被験筋の筋活動を比 較するため, 一元配置分散分析とその後の多重比較法と して Tukey 検定を行った，有意水準は 5\%とした。統計 解析には IBM SPSS Statistics 24 for Windows を使用 した。

\section{III. 結 果}

結果を表 1 に示した。 RF の筋活動（\% IEMG）は, 肢位(1)が $44.4 \pm 12.7 \%$, 肢位(2)が $53.1 \pm 14.9 \%$, 肢位(3) が $71.7 \pm 17.2 \%$ であり, 肢位(1)と肢位(2)に比べて肢位(3) に有意な増大が認められた $(\mathrm{p}<0.01)$. VMの筋活動は, 肢位(1)が $97.1 \pm 33.6 \%$, 肢位(2)が $98.4 \pm 33.6 \%$, 肢位(3) が $91.4 \pm 43.2 \%, V L の$ 筋活動は, 肢位 (1)が $99.4 \pm$ $26.4 \%$ ，肢位(2)が $99.4 \pm 24.7 \%$ ，肢位(3)が $90.8 \pm 31.2 \%$ であり, 肢位の違いによる有意差が認められなかった。

\section{IV. 考 察}

今回の結果から，いずれの肢位のセッティングにおい ても VMと VLに大きな筋活動が得られ，肢位による 有意差は認められなかった。一方，いずれの肢位におい ても RF の筋活動はVM と VL に対して低值であった。 背臥位でのセッティングは大腿四頭筋のみならず股関節 伸筋にも筋活動が生じる 16)。これは, 背臥位でのセッ ティングが膝窩を床面に押しつける運動であり，等尺性
表 1 各肢位での筋活動（％ IEMG）

\begin{tabular}{lccl}
\hline & 肢位(1) & 肢位(2) & 肢位(3 \\
\hline $\mathrm{RF}$ & $44.4 \pm 12.7$ & $53.1 \pm 14.9$ & $71.7 \pm 17.2^{*, \dagger}$ \\
$\mathrm{VM}$ & $97.1 \pm 33.6$ & $98.4 \pm 33.6$ & $91.4 \pm 43.2$ \\
$\mathrm{VL}$ & $99.4 \pm 26.4$ & $99.4 \pm 24.7$ & $90.8 \pm 31.2$ \\
\hline
\end{tabular}

平均值 \pm 標準偏差. $\mathrm{RF}$ : 大腿直筋, $\mathrm{VM}$ : 内側広筋, $\mathrm{VL}$ : 外側広筋. $*: \mathrm{p}<0.01$ (vs 肢位(1)), $\dagger: \mathrm{p}<0.01$ ( vs 肢位(2)).

運動であるものの膝関節伸展と股関節伸展を同時に行う 運動であるからと考えられる。単関節筋であるVMと VL は膝関節伸展に作用するが, 二関節筋である RF は 股関節屈曲の作用を有するためセッティングの股関節運 動に拮抗して十分な筋活動が得られなかったと考えられ る。なお，腹臥位でのセッティングにおいても背臥位と 同様に股関節伸展運動が生じ RF の筋活動が抑制される と考えられるが, 非支持側の股関節を最大伸展位に保持 することで他の肢位に比べて RF の筋活動が有意に増大 し，比較的大きな筋活動が得られた。河村らは，一側下 肢のレッグプレスを対側股関節の屈曲運動と同時に行う ことで, 単独で行うよりもレッグプレス側の大殿筋と八 ムストリングスの筋活動が増大したと報告している ${ }^{13)}$. 対側股関節を屈曲することで腸腰筋の収縮により骨盤前 傾モーメントが生じるが，これに対してレッグプレス側 の大殿筋とハムストリングスの収縮を増大させ，骨盤後 傾モーメントを引き起こすことで骨盤を安定させている と考察している ${ }^{13)}$. 腹臥位にて非支持側の股関節を最 大伸展位に保持した片脚セッティングでは, 非支持側の 股関節伸筋の筋活動が増大することから骨盤後傾モーメ ントが生じる。このとき，骨盤を安定させるために支持 側の股関節屈筋の筋活動を増大させ, 骨盤前傾モーメン トを引き起こしていると考えられる， RF は下前腸骨棘, 寛骨臼の上縁ならびに関節包に付着し，大腿四頭筋で唯 一の二関節筋であり股関節屈曲の作用も有する.このこ とから, 腹臥位にて非支持側の股関節を最大伸展位に保 
持した片脚セッティングでは，骨盤を安定させるために 股関節屈曲の作用を有する RF の筋活動を増大させてい たと考えられる。また，一側下肢の筋収縮は対側下肢の 筋活動を増大させることが知られており 17,18), なかで も対側同名筋よりも対側拮抗筋に強い収縮を引き起こす 可能性が報告されている ${ }^{18)}$ ，腹臥位にて非支持側の股 関節を最大伸展位に保持した片脚セッティングでは非支 持側の股関節伸筋の筋活動が増大寸ると考えられるため, 股関節屈筋としても作用する支持側の RF の筋活動が増 大したと推察される。ただし，本研究では非支持側の大 殿筋やハムストリングス, 支持脚の腸腰筋などの筋活動 を測定しておらず，今後これらの筋活動を測定し，非支 持側の大殿筋やハムストリングスの筋活動が支持側の股 関節屈筋に与える影響について検討しなければならな い.また，非支持側の股関節伸展に抵抗を与えることで 非支持側の大殿筋とハムストリングスの筋活動が増大し, 支持側の RF の筋活動が増大することが考えられる。こ のため，非支持側の股関節伸展に対する抵抗負荷が支持 側の RF の筋活動に及ぼす影響についても検討する必要 がある。腹臥位での股関節伸展は股関節伸筋群だけでな く腰部傍脊柱筋や多裂筋の筋活動が増大する ${ }^{19)}$ ，腰部 傍脊柱筋をはじめとする背筋群は脊柱の伸展運動を引き 起こすため，腹臥位にて非支持側の股関節を最大伸展位 に保持した片脚セッティングでは姿勢を安定させるため にも拮抗筋である腹筋群の筋活動を増大させている可能 性がある。腹筋群の筋活動は大腿直筋の筋活動を増大さ せることが知られており20,21)，セッティングにおける 腹筋群の筋活動が RF の筋活動を促通したと推察され る。たたし，腹筋群と大腿直筋の筋活動は運動方法に よっても変化するため20,21), 今後は各セッティングに おける腹筋群や背筋群の筋活動についても検討しなけれ ばならない。

大腿直筋は二関節筋であり膝関節伸展だけでなく股関 節屈曲の作用を有することから，各種動作において広筋 群と比べて特異的な役割を有することが知られている. 歩行における大腿四頭筋の主な作用は立脚期に生じる膝 関節屈曲を制動することであるが 22)，大腿直筋は前遊 脚期から遊脚初期にかけて活動し，股関節の屈曲運動を 引き起こすとともに膝関節の屈曲運動を制動する役割を 有する 22)。 小澤らは, 最速歩行では最適歩行に比べて 下肢の筋活動が増大し，なかでも遊脚期において大腿直 筋の筋活動が著明に増大したと報告している23)。これ は，下肢の振り出しにおける股関節屈曲運動において大 腿直筋が大きく活動していることが考えられる。また， 大腿直筋はスポーツにおいて肉離れの頻度が高く24), パフォーマンスにも影響を与える ${ }^{25)}$ ，大腿直筋の肉離 れは遠心性収縮の際に生じるとされ，走行では後方に蹴 り出した脚を前方に振り上げる切り返しの際に生じやす いとされている26)。このように大腿直筋は大腿四頭筋
のなかでも特異的な作用を有することから，筋力低下の 予防や筋力向上を目的とした積極的な介入が必要である と考えられる。

本研究から, 腹臥位にて非支持側の股関節を最大伸展 位に保持した片脚セッティングは，他の肢位に比べて $\mathrm{RF}$ の筋活動の有意な増大が認められた。背臥位での セッティングはVM と VLに比較的大きな筋活動が得 られたものの RF の筋活動が小さいという特徴があっ た。しかし，腹臥位での片脚セッティングにおいて非支 持側の股関節を最大伸展位に保持することでVM と VL の大きな筋活動のみならず, RF に対しても比較的大き な筋活動を得ることができた。このことから，腹臥位に おける非支持側の股関節を最大伸展位に保持した片脚 セッティングは，RF を含む大腿四頭筋の大きな筋活動 を得るための方法として有用であることが示唆された。 今後は介入研究を通じて臨床的な有用性をさらに検討し たい.

\section{引用文献}

1) 山本利春 : スポーツ傷害の発症要因とコンディショニングの 教育. 臨床スポーツ医学臨時増刊号, 2011, 28: 11-15.

2) 池添冬芽, 浅川康吉, 羽崎 完 - 他：高齢者に打ける起居 移動動作自立に必要な滕伸展筋力について。理学療法科学, 1997, 12: 179-181.

3) 石橋英明 : 関節のアンチエイジング 変形性膝関節症になら ないためには. Modern Physician, 2014, 34: 1301-1305.

4) 中村隆一, 斎藤 宏: 臨床運動学, 第2 版. 医歯薬出版, 東京, 1990, pp167-169.

5) 藤井俊宏: 臥床に伴う体力低下に関する研究.リハビリテー ション医学, 1993, 30: 63-70.

6) Sieri T, Beretta G: Fall risk assessment in very old males and females living in nursing homes. Disabil Rehabil, 2004, 26: 718-723.

7) Lord SR, Clark RD, Webster IW: Physiological factors associated with falls in an elderly population. J Am Geriatr Soc, 1991, 39: 1194-1200.

8) Lord SR, Ward JA, Williams P, et al.: Physiological factors associated with falls in older community-dwelling women. J Am Geriatr Soc, 1994, 42: 1110-1117.

9) 服部一郎, 細川忠義, 和才嘉昭:リハビリテーション技術全書, 第2版. 医学書院, 1984, pp506-507.

10) 千田益生 : 変形性膝関節症の運動療法ガイド 保存的治療か ら術後リハまで。日本医事新報社，東京，2014，pp76-87.

11) 羽崎 完, 市橋則明 : 大腿四頭筋の Muscle Settingの肢位 が大腿四頭筋筋活動に与える影響。理学療法科学，1996, 11: 81-84.

12) 井原秀俊, 三輪 恵, 石橋俊郎 -他 : 足指訓練の持続効果一 訓練中止 3 力月後の検討一. 整形外科と災害外科, 1997, 46: 393-397.

13) 河村顕治, 岡田育子, 松尾高行 : 対側股関節屈曲が下肢閉 運動連鎖筋出力に及ぼす影響. 日本臨床バイオメカニクス 学会誌, 2004, 25: 315-319.

14) Nakajima M, Kawamura K, Takeda I: Electromyographic 
analysis of a modified maneuver for quadriceps femoris muscle setting with co-contraction of the hamstrings. J Orthop Res, 2003, 21: 559-564.

15) Hislop HJ, Montgomery J : 新 · 徒手筋力検査法, 第 8 版. 津山直一 - 他 (訳), 協同医書出版, 東京, 2008, pp224227.

16）事柴壮武, 浦辺幸夫, 前田慶明・他：体幹固定性の違いと 股関節角度の変化が大腿四頭筋セッティングの下肢筋筋活 動に及ぼす影響. 理学療法の臨床と研究, 2013, 22: 21-24.

17) 富田 浩, 柳澤 健：一側下肢の筋収縮が対側下肢の筋放 電に及ぼす影響．PNFリサーチ，2013，13: 18-29.

18) 富田 浩, 中野香緒里, 成田あゆみ・他：一側下肢の筋収 縮が対側下肢の筋活動に及ぼす影響（予備実験）。理学療法 群馬, 2007, 18: 21-25.

19) 世古俊明, 隅元庸夫, 高橋由依・他：徒手筋力計を用いた 座位での股関節伸展筋力測定法の有用性. 理学療法科学, 2015, 30: 75-79.

20) Andersson EA, Nilsson J, Ma Z, et al.: Abdominal and hip flexor muscle activation during various training exercises. Eur
J Appl Physiol Occup Physiol, 1997, 75: 115-123.

21) 半田 徹, 加藤浩人, 長谷川伸・他：腹部トレーニング 7 種目に扔ける腹直筋上部, 腹直筋下部, 外腹斜筋㧍よび大 腿直筋の筋電図学的研究. 体育学研究, 2009, 54: 43-54.

22) Perry J: Gait analysis. Normal and pathological function. SLACK Incorporated, New Jersey, 1992, pp98-107.

23) 小澤実奈, 村田 伸, 空場勝之 - 他: 最適歩行と最速歩 行中の歩行パラメーターと下肢筋活動の比較. Japanese Journal of Health Promotion and Physical Therapy, 2016, 5: 179-183.

24) 林 典大, 浅野招裕 : 関節機能解剖に基づく整形外科運動 療法ナビゲーション下肢. MEDICAL VIEW, 東京, 2008, pp88-91.

25) 稲見崇孝, 宮川博文, 井上雅之・他 : 筋の形態的および機 能的考察を行った陳旧性大腿直筋肉ばなれの一症例。日本 臨床スポーツ医学会誌, 2012, 20: 364-369.

26) 奥脇 透:ランニング障害のリハビリテーションとリコンディ ショニングーリスクマネジメントに基づいたアプローチー. 増田雄一(編), 文光堂, 東京, 2012, pp79-87. 